\title{
縦渦の定常揚カにより駆動する円柱翼風車の開発
}

\author{
坂本 夏澄*1, 宇高 啓太 ${ }^{* 2}$, Withun HEMSUWAN³, 高橋 勉 ${ }^{* 2}$
}

\section{Development of circular cylinder blade wind turbine driven by longitudinal vortex}

\author{
Kasumi SAKAMOTO $^{* 1}$, Keita UDAKA ${ }^{* 2}$, Withun HEMSUWAN ${ }^{* 3}$ and Tsutomu TAKAHASHI ${ }^{* 2}$ \\ ${ }^{* 1}$ Department of Science of Technology Innovation, Nagaoka University of Technology \\ 1603-1 Kamitomioka-machi, Nagaoka-shi, Niigata 940-2188, Japan \\ ${ }^{* 2}$ Department of Mechanical Engineering, Nagaoka University of Technology \\ 1603-1 Kamitomioka-machi, Nagaoka-shi, Niigata 940-2188, Japan \\ ${ }^{* 3}$ School of Mechanical Engineering, Suranaree University of Technology \\ 111 University Avenue, Muang District, Nakhon Ratchasima 30000, Thailand
}

Received: 12 October 2020; Revised: 13 December 2020; Accepted: 28 January 2021

\begin{abstract}
It is known that the longitudinal vortex alternately and periodically forms diagonally backward of the upstream cylinder of the cruciform system consisted of the upstream cylinder and the downstream strip-plate and causes the strong periodic lift force on the upstream cylinder. We have had a new concept to form a longitudinal vortex steadily at a fixed position, in where the gap between the upstream cylinder and the strip-plate, and it generates a steady lift force on the upstream cylinder. A new wind turbine, which has a circular cylinder blade and is driven by the longitudinal vortex, has been designed by this concept. In this study, the flow-visualization by the smoke-wind tunnel confirms the generation of the longitudinal vortex that was predicted by the numerical analysis. The cross-sectional size of the vortex depends on the diameter of the circular cylinder blade and increasing the number of blades does not affect its size strongly. The steady lift force acting on the circular cylinder blade was measured and the relationship with the relative attack angle which is determined by the mainstream flow velocity and the moving velocity of the cylinder blade in crossflow direction was examined. At a small gap between the circular cylinder and the strip-plate, the fluid force acts to reduce the move. When the normalized gap by the cylinder diameter is larger than 0.35 , the fluid force causes to accelerate the cylinder faster in the small relative attack angle region. The performance characteristics of the cylinder blade wind turbine were evaluated and they show the similar characteristics to the drag type wind turbine.
\end{abstract}

Keywords : Renewable energy, Wind turbine, Circular cylinder blade, Longitudinal vortex, Necklace vortex, Sready lift force, Flow-visualization, Wind tunnel experiment

\section{1. 緒言}

一様流中に置かれた柱状物体がカルマン渦の周期的な流出により共振を起こす現象は,「カルマン渦励振」とし てよく知られている.この現象を抑制する方法として円柱断面形状を変化させる方法や円柱表面に突起を付ける など様々な方法が提案されている(Blevins, 2001). これに対して著者らのグループでは，振動する柱状物体には手 を加えずに下流に別の物体を設置して流れを変化させて振動を抑制する方法を検討した．そして，カルマン渦励 振状態にある円柱に対して，円柱と主流の双方に直交する，すなわち十字交差配置となるように下流に新たな円 柱を所定の間隔を持たせて配置することで，効果的にカルマン渦励振を抑制できることを見いだした(裴他, 1993). このとき，下流への円柱の配置によりカルマン渦は消失するが，交差部近傍にはネックレス型あるいはトレーリ

No.20-00365 [DOI:10.1299/transjsme.20-00365], J-STAGE Advance Publication date : 5 February, 2021

*1 正員, 長岡技術科学大学大学院 工学研究科 技術科学イノベーション専攻（下940-2188 新潟県長岡市上富岡町 1603-1）

*2 正員, 長岡技術科学大学大学院 工学研究科 機械創造工学専攻

*3 School of Mechanical Engineering, Suranaree University of Technology (111 University Avenue, Muang District, Nakhon Ratchasima 30000, Thailand)

E-mail of corresponding author: ttaka@nagaokaut.ac.jp 
ング型の縦渦が形成される。十字交差柱状物体における縦渦の形成およびその形状については 2 つの柱が用い られた円柱・円柱系に関して Fox(1990,1991)や裴ら(1992)が報告している. また，下流に配置された円柱を平板に 置き換えた円柱・平板系については Shirakashi ら(1994)や Takahashi ら(1999), 加藤ら(2007)の報告がある. 図 1 は Takahashi ら(1999)により提示された円柱・平板系におけるトレーリング渦およびネックレス渦の模式図である. また，角柱・平板系においても同様に縦渦が形成されることを川畑ら(2011)が報告している.

一様流中に固定された十字交差柱状物体において発生する縦渦は，カルマン渦のように上流に配置された柱状 物体の斜め後方において交互に形成と消失を繰り返す，縦渦の形成・消失は周期性が高く，その周波数は流速や 形状因子の影響を受ける. 図 1 の縦渦は上流円柱からみて斜め後方の上側に形成されているが，次の瞬間には円 柱中心軸を含む水平面に対して対称の位置, 寸なわち斜め後方の下側において縦渦が形成される. 縦渦の形成・ 消失に同期して上流の柱状物体には変動揚力が作用し，その励振力はカルマン渦の周期的流出による変動揚力よ りも大きい，著者らのグループは，柱状物体が主流に対して垂直方向（クロスフロー方向）に移動可能なように 弾性支持される場合に縦渦による渦励振現象, 寸なわち「縦渦励振」が発生することを見いだした(Kato et al., 2012, Koide et al., 2006, 2017). 一般に渦励振現象とは渦流出周波数と系の固有振動数が一致する場合に発生する共振現 象である. カルマン渦の流出周波数は流速にほぼ比例することからカルマン渦励振は渦流出周波数が固有振動数 とほぼ一致する狭い流速範囲でのみ発生する現象である. カルマン渦励振を利用した渦励振発電システム VIVACE は海流など流速変動が小さい流れを対象とすることで渦励振が発生する流速範囲の狭さをカバーした (Bernitsas et al., 2008). また，流速変化に合わせて固有振動数を能動的に制御する方法や，流速を渦流出周波数に 一致させるように制御する方法などもカルマン渦励振発電の実用化には検討できるが，いずれも構造が複雑でコ ストと耐久性に問題がある. 一方, 縦渦の流出周波数も流速の増加に伴い増加することから特定の流速域におい て共振による振動現象が発生するが, 本来の共振発生流速を大きく逸脱しても縦渦の 3 次元的構造が自律的に変 化して流出周波数が系の固有周波数に一致し振動が継続する.この同期現象はカルマン洞励振でも観察されるが, 縱渦の同期流速範囲はカルマン渦に対して遥かに広く, 円柱・平板系の場合は数十倍の範囲まで拡大される(Koide et al., 2006). 著者らのグループは縱渦励振の励振力の強さと同期流速範囲の広さ，および構造の単純さを活用し た縦渦励振発電システムを発表した(小出他, 2011). 縦渦励振発電は複雑な機構が不要で広い流速範囲での発電を 可能とする技術であり, 渦励振発電の実用化に際して有利な特性を有する.

縦渦励振現象からわかるように縦渦は，上流に配置された柱状物体に対して極めて強い励振力を与えるが，十

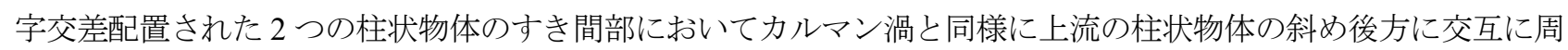
期的に発生と消失を繰り返す，条件によっては不規則的に発生する場合もあるが，縦渦により上流の柱状物体に 作用する揚力は変動しており, 時間平均的にはゼ口, 寸なわち定常揚力は発生しない。このため, 縦渦は柱状物 体を一方向にのみ動か寸動力としては作用しない，著者らのグループは，この強い励振力を生み出寸縦渦を利用 して上流の円柱に定常揚力を作用させるアイディアを得て縦渦を円柱の所定の位置に定在化させることに成功し， その成果の例として図 2 に示寸新しい風車の駆動システムを提案した(高橋他, 2016, Takahashi et al., 2016). 塩ビ管 製の円柱翼が回転軸に取り付けられ，その下流にはリング状平板が所定の寸き間となるように取り付けられてい る.この装置を一様流中に設置すると円柱翼は安定した回転数で回転し続けた．また，円柱翼の断面形状が対称 であることから予想できるとおり，この風車は左右どちらの方向にも回転した．回転方向は初動の方向に依存寸 る. この円柱翼風車は単純な形状で構成されており, 形状を特徵づける主要な因子は円柱翼の直径 $d$ と長さ $l$, リ ング状平板の直径 $D$ とリング幅 $w$ ，そして円柱翼とリング状平板の寸き間 $s$ のつである.

本論文では周期性の強い縦渦を風車の動力源として利用できる, 定常揚力の発生を可能とした縦渦の定在化現 象について, その基本的なアイディアとメカニズムを説明し, 可視化により縦渦の定在化を証明する. さらに, 縦渦により発生する定常揚力を実験により明らかにし, 円柱翼風車の動力特性について検討する. 


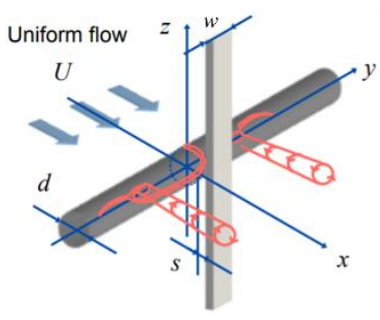

(a) Trailing vortex

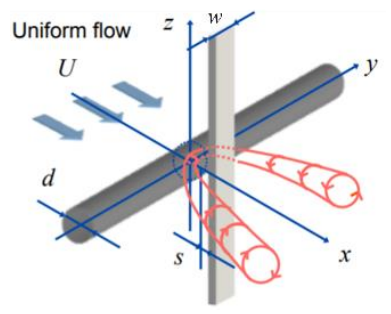

(b) Necklace vortex

Fig. 1 Longitudinal vortices of cruciform system of upstream circular cylinder and downstream strip-plate (Takahashi et al., 1999).

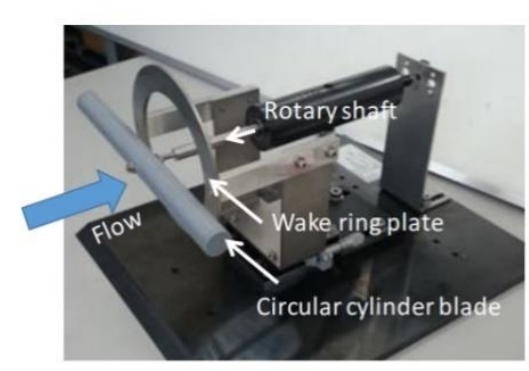

(a) Photograph of first trial device

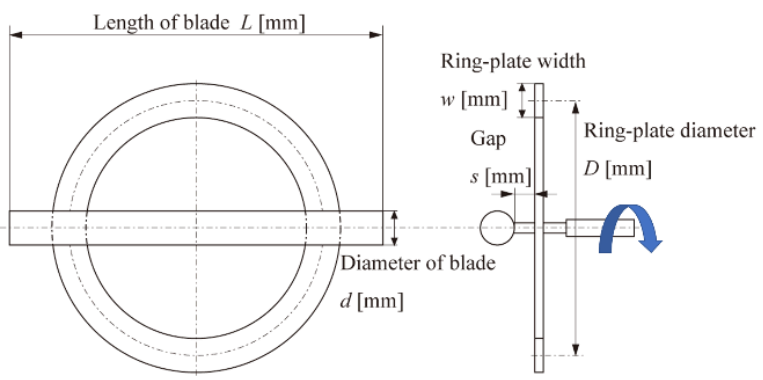

(b) Schematic diagram and each parameter

Fig. 2 The first trial device of circular cylinder blade wind turbine driven by longitudinal vortex. $d=20 \mathrm{~mm}, w=20 \mathrm{~mm}, L=220 \mathrm{~mm}$, $D=155 \mathrm{~mm}, s=7 \mathrm{~mm}(s / d=0.35)$ (Takahashi et al., 2016).

\section{2. 周期的に形成・消失する縦渦の定在化に関する考察}

一様流中で流れに直交するように設置された十字交差配置の円柱と平板の交差部付近では, 図 1 で示したよう に縦渦が形成される．縦渦はカルマン渦のように上流に配置された円柱の斜め後方において交互に形成と消失を 繰り返す. 縦渦の形成・消失は周期性が高く，その周波数は流速や形状因子に影響を受ける. 図 1 に示寸縦渦は 円柱からみて斜め後方の上側に形成されている例であるが，次の瞬間には円柱中心軸を含む水平面に対して対称 の位置（斜め下側）において縦渦が形成される，ネックレス渦の場合，下流に配置された平板を含む円柱の断面 で見ると図 3(a)に示寸ように円柱と平板の交差部の寸き間において上側または下側に渦の断面が存在する状態が 交互に発生する．この縦渦発生の位置の周期的な変動により，円柱にはクロスフロー方向の周期的な流体力が作 用する，なお，図 1(b)および図 3 の模式図において，ネックレス渦の回転方向は Hemsuwan ら(2018)により報告 された数值解析の結果に基づいて記載した.

縦渦の発生位置を図 3(a)の円柱の上側または下側のいずれか一方において定常的に存在する状況を得ることが できれば，円柱にはクロスフロー方向の定常的な揚力が作用する．縦渦の発生位置を固定する方法として，本論 文では円柱のクロスフロー方向への移動による相対迎角の形成を試みた．図 3(b)に示すように, 円柱が平板に沿 って上側に一定速度で平行移動する状況を考える，この場合，主流速度と円柱の移動速度の合成により円柱には 相対的な迎角が発生する．下流に平板がなければ，相対迎角が発生しても円柱断面が軸対称形であることから， 流れ場は相対迎角の分だけ方向が変わるだけで円柱まわりや下流の流れ場は変わらない. しかし，平板が所定の 寸き間を持って配置されている場合，相対迎角の発生により円柱と平板の寸き間は円柱の進行方向とその反対側 で流れ場は非対称となる.すき間が広い円柱の進行方向の逆側にネックレス渦が円柱の移動に追従しながら定在 的に発生し，これにより定常的な揚力が円柱に作用すると仮定した.

この仮定は図 2 で示した簡単な模型により検証できる. 図 3 の模式図のように円柱を平板に沿って平行移動さ せる代わりに，円柱の長手方向の中心に回転軸を取り付けることでプロペラのように回転できるようにし，平板 をリング状にして円柱回転軸と同心状となるように下流に設置する. リング状平板の直径が十分に大きければ円 柱との交差部近傍の流れは図 1 や図 3 の模式図と近い状態になる. そして, 円柱を左右どちらかの方向に初速を 与えて回転させることで，図3(b)の流れ場を実現できる. 図 2 の模型を用いた実験より，主流速度が低い場合は 円柱にどちらかの回転方向に初速を与えることでその方向に回転を継続し, 所定の回転数に達するまで角加速運 
動した後に定常回転状態になる. 主流速度が $3 \mathrm{~m} / \mathrm{s}$ 程度を越えると初速を与えることなく, 円柱は静止状態から 自立的に回転を始める. 高流速では瞬時に一方向に回転を開始するが, 低流速域では静止状態から回転を開始後, 回転方向が 1, 2 回変化した後に一方向に向けて加速を始める場合もある.

このように，風車として動作することから相対迎角によりネックレス渦が定在化するという仮説は正しいこと が理解できる.さらに, Hemsuwan ら(2018)による数值解析からもネックレス渦が円柱の移動に追従しながら形成 されることが示唆されている. 本論文では，このネックレス渦の定在化に対して流れを可視化し，仮説や数值解 析結果の妥当性を明らかにする．また，相対迎角が発生したときに円柱に対して作用する流体力を実験により測 定し，定常的な揚力の発生を証明するとともに，相対迎角と揚力の関係を明らかにする。このための実験方法及 および装置について，次に説明を行う。

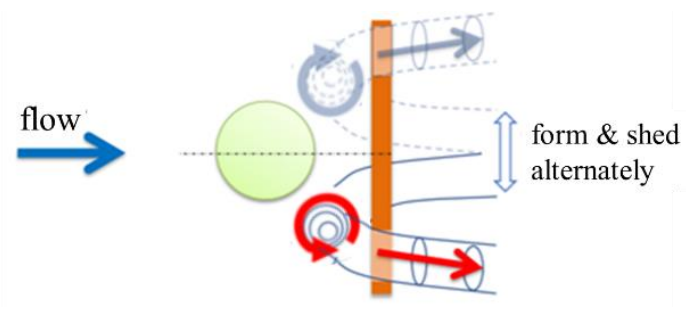

(a) Fixed cylinder system

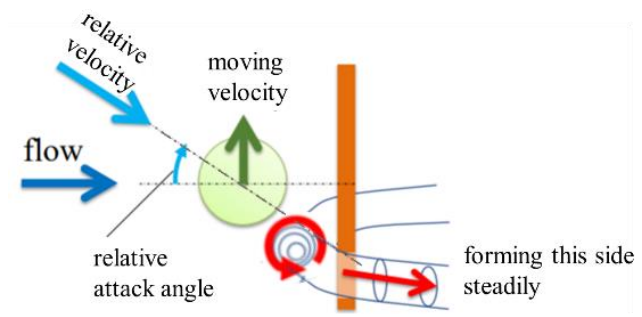

(b) Parallel moving cylinder with a constant moving velocity

Fig. 3 Necklace vortices at cross-section of cruciform system of upstream circular cylinder and downstream strip-plate.

\section{3. 実験装置および手順}

\section{$3 \cdot 1$ 円柱翼風車の構造と円柱翼の形状}

1 本の長い円柱翼を用いた単独円柱翼風車の写真および概略図は図 2 のとおりである. 直径 $d=20 \mathrm{~mm}$, 長さ $L$ $=220 \mathrm{~mm}$ の塩ビ管製の円柱翼は, 回転軸の中心から左右に $L / 2=110 \mathrm{~mm}$ となるように回転軸に固定される. リ

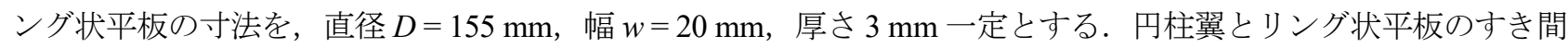
の無次元数（以下，すき間比）は $s / d=0 \sim 0.5$ の範囲で任意に設定可能である.

円柱翼を多翼化する場合，回転軸付近で主流が抜けにくくなり抗力が増加する．縦渦による揚力発生は円柱と リング状平板の交差部近傍のみで発生する(Hemsuwan et al., 2018)ことから, リング状平板近傍以外は円柱直径を 小さくすることで，回転抵抗や抗力を下げるとともに，多翼化しやすい形状にできる．揚力の発生に必要な長手 方向の範囲だけを太くした円柱翼を段つき円柱翼と名付ける．段つき円柱翼は翼数に合わせて均等な角度で回転 軸のハブに取り付けられる. 翼数 $N=8$ の段付き円柱翼風車の写真および $N=2$ の概略図を図 4 に示す. リング 状平板の寸法は $D=155 \mathrm{~mm}, w=20 \mathrm{~mm}$, 厚さ $3 \mathrm{~mm}$ とする. 段付き円柱翼はテフロン製で, 回転軸に固定され た直径 $\varphi 30 \mathrm{~mm}$ ，幅 $20 \mathrm{~mm}$ のハブに等間隔で取り付けられる. 縦渦による揚力が発生する有効部分の直径を $d=$ 20 および $28 \mathrm{~mm}$, 回転軸に近い支持部の直径を $d^{\prime}=6 \mathrm{~mm}$, 有効部分のリング状平板の内外縁からの突き出し長 さを $l_{P}=10 \mathrm{~mm}$, すなわち, 有効部分の長さを $l=40 \mathrm{~mm}$ とする. 円柱翼の全長は $L=195 \mathrm{~mm}$ である. すき間比 は単独円柱翼風車の場合と同様に任意の值に変更可能である.

Table 1 に実験に用いた円柱翼型風車の装置の形状条件をまとめて示す. 


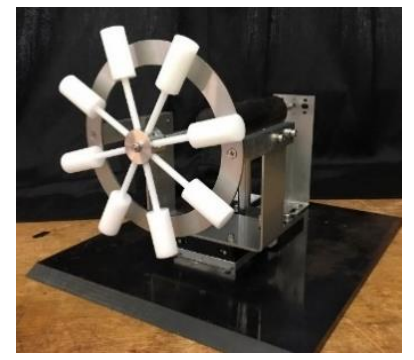

(a) Photograph of stepped cylinder blade wind turbine $(N=8)$
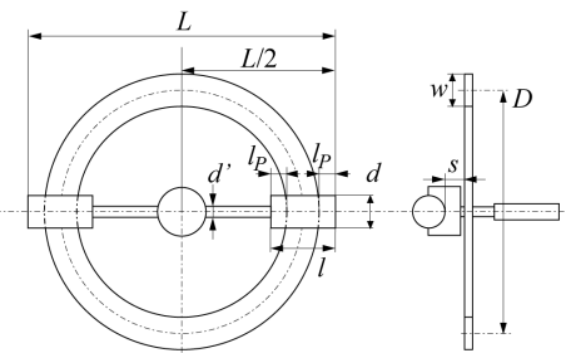

(b) Schematic diagram and parameters $(N=2)$

Fig. 4 Photographs and schematic diagrams of stepped cylinder blade wind turbine.

Table 1 Parameters of experimental conditions.

\begin{tabular}{l|c|c}
\hline & Circular cylinder blade wind turbine & Stepped cylinder blade wind turbine \\
\hline \hline Gap ratio $s / d[-]$ & $0 \sim 0.5$ & 0.35 \\
\hline Ring-plate width $w[\mathrm{~mm}]$ & 20 & 20 \\
\hline Blade diameter $d[\mathrm{~mm}]$ & $220(110)$ & $20,28\left(d^{\prime}=6\right)$ \\
\hline Blade length $L(L / 2)[\mathrm{mm}]$ & & 155 \\
\hline Ring-plate diameter $D[\mathrm{~mm}]$ & $(2)$ & $195(97.5)$ \\
\hline Blade number $N$ & 100 & $2,4,8$ \\
\hline Blade effective length $l[\mathrm{~mm}]$ & & 40 \\
\hline Blade protruding length $l_{p}[\mathrm{~mm}]$ & & 10 \\
\hline
\end{tabular}

\section{$3 \cdot 2$ 風洞装置}

図 5 に風車装置が設置されたテストセクションの模式図とその寸法, テストセクション入りロからの風車装置 およびリング型流速計の設置位置を示寸. テストセクションの断面は $320 \mathrm{~mm}$ の正方形で, 長さは $1200 \mathrm{~mm}$ であ り, 速度範囲は $U=2 \sim 40 \mathrm{~m} / \mathrm{s}$, 乱流強度は 0.3 0.6\%の範囲である(Kato et al., 2012). 風車は, 円柱翼の上流面がテ ストセクションの入口を $0 \mathrm{~mm}$ としたときの $840 \mathrm{~mm}$ 下流，回転軸がテストセクション断面の中心，すなわち， 高さ $160 \mathrm{~mm}$, 幅 $160 \mathrm{~mm}$ に位置するように設置される. テストセクション内の流速 Uはリング型流速計(小出他, 2001)により測定され，この流速計に付属した熱線プローブの先端がテストセクション入口を $0 \mathrm{~mm}$ としたときの $200 \mathrm{~mm}$ 下流に位置寸る.

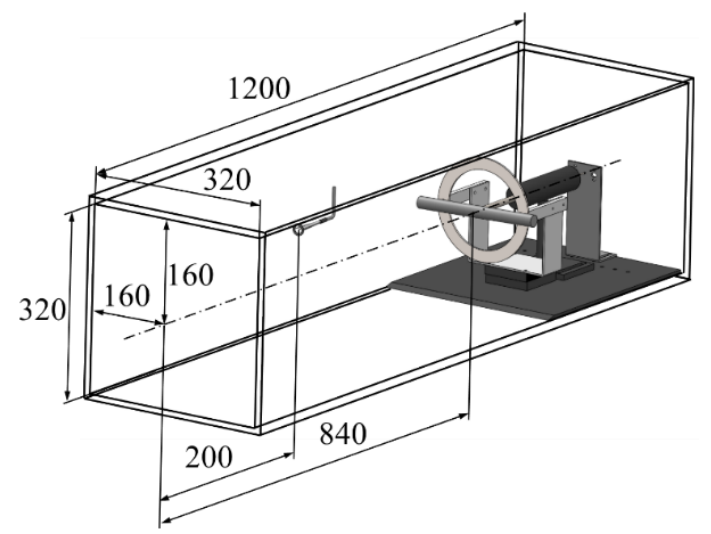

Fig. 5 Schematic diagram of test section and wind turbine setting. The unit of dimension is $\mathrm{mm}$.

\section{$3 \cdot 3$ 流体力の測定方法および解析手順}

流体力測定装置の概観を図 6(a) に示す。一定流速において単独円柱翼型風車を任意の回転数で回転させること で任意の相刘迎角を設定し，その時に円柱翼に作用するクロスフロー方向の力である揚力を測定する．装置は図 
2 の風車を回転軸の先端に取り付けたモータ(BLM230HP-5S, ORIENTAL MOTOR Co., Ltd.)により, 任意の回転数 $n[\mathrm{rpm}]$ で強制回転する構造となっている. 図 6(b)のようにモータと回転軸の間にトルクメータ (UTMII-0.2N·m, Unipulse Co., Ltd.)が接続されており， 円柱翼回転時に流れにより受けるクロスフロー方向の力をトルク $T_{z}[\mathrm{~N} \cdot \mathrm{m}]$ として測定し, 流体力係数 $C_{z}$ [-]を算出する. 図 7(b)のように円柱翼がクロスフロー方向に運動するとき, 主流速 $U$ と円柱翼の回転速度 $V[\mathrm{~m} / \mathrm{s}]$ が合成され，主流を基準として $\alpha[\mathrm{deg}]$ の迎角を持った相対流速 $U_{r}[\mathrm{~m} / \mathrm{s}]$ を受けるこ ととなる.このとき, 密度 $\rho\left[\mathrm{kg} / \mathrm{m}^{3}\right]$ の流体中で直径 $d$, 長さ $l$ の円柱にかかる流体力 $F_{z}[\mathrm{~N}]$ は

$$
F_{z}=\frac{1}{2} C_{z} \rho d l U^{2}
$$

となる. 主流速 $U$ と回転速度 $V$ の成す迎角 $\alpha$ は,

$$
\alpha=\tan ^{-1}\left(\frac{V}{U}\right) \cdot \frac{180}{\pi}
$$

交差部における円柱翼クロスフロー方向の速度 $V$ は, 円柱翼の回転数 $n$ とリング状平板直径 $D$ を用いて,

$$
V=\frac{D}{2} \cdot \frac{2 \pi n}{60}
$$

となる．縦渦による流体力 $F_{z}$ は図 7(a)のように力点が 2 か所あることを考慮すると，

$$
F_{z}=\frac{T_{z} / 2}{D / 2}
$$

となり， $F_{z}$ を式(1)に入力することで $C_{z}$ を得る.

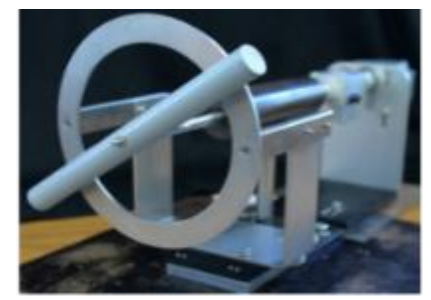

(a) Photograph of measurement apparatus of fluid force

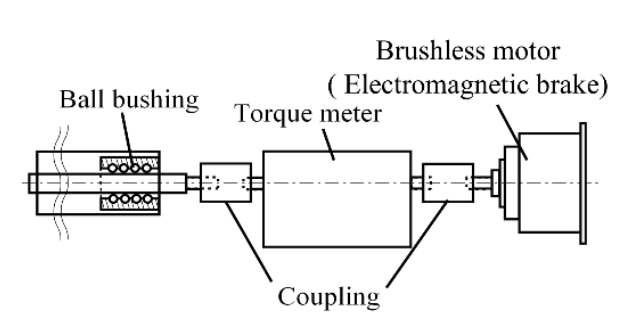

(b) Schematic of setup of measurement instrument

Fig. 6 Setup of measurement apparatus for measurement of fluid force.

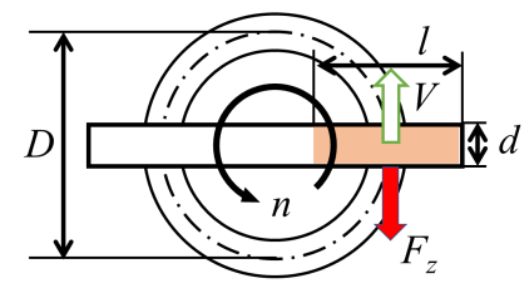

(a) Front view

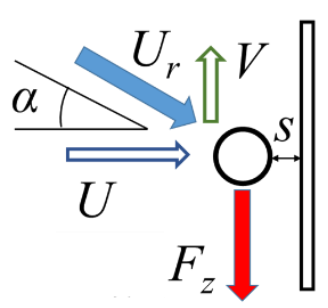

(b) Side view

Fig. 7 Schematic of flow field on rotating cylinder.

\section{3-4 風車性能の測定方法および評価手順}

風車性能測定装置では, 図 6 に示したモータを電磁ブレーキ(HB0.5, OGURA CLUTCH Co., Ltd.)に取り換える. 一定流速において定常回転している風車に対して, 電磁ブレーキからの負荷を増加させることにより回転数が $n$ $=0$ になるまで $n$ を段階的に減少させ, 回転数 $n$ およびトルク $T_{b r a k e}[\mathrm{~N} \cdot \mathrm{m}]$ をトルクメータにより測定する. この $n$ と $T_{\text {brake }}$ の関係を用いて, 風車の性能を評価するために一般的に用いられる周速比 $\lambda[-]$ に対するトルク係数 $C_{q}[-]$ とパワー係数 $C_{p}[-]$ の関係を以下の式(5) (7)により算出する.

$$
\lambda=\frac{\pi n L}{60 U}
$$




$$
\begin{gathered}
C_{q}=\frac{T_{\text {brake }}}{\rho A L U^{2} / 4} \\
C_{p}=\frac{4 \pi n T_{\text {brake }}}{60 \rho A U^{3}}
\end{gathered}
$$

ここで, $A\left\{=\pi\left(L * 10^{-3}\right)^{2} / 4\right\}\left[\mathrm{m}^{2}\right]$ は回転中の円柱翼の受風面積である.

\section{$3 \cdot 5$ 可視化方法および評価手順}

定常回転する円柱翼とリング状平板の間にネックレス渦が定在的に形成されることを確認し，円柱翼近傍のネ ックレス渦の断面直径を計測するために可視化を行う。明瞭な画像を得るために主流速度は各種の条件において 円柱翼が定常回転する最低流速（ $U=3 \sim 4 \mathrm{~m} / \mathrm{s})$ とする. 風洞内に設置した煙導入管による流れの乱れを抑制する ために, 長辺 $3 \mathrm{~mm}$, 短辺 $2 \mathrm{~mm}$ のセルを有する高さ $320 \mathrm{~mm}$, 幅 $320 \mathrm{~mm}$, 流れ方向長さ $50 \mathrm{~mm}$ の整流格子を, 整流格子の下流端から円柱翼の上流面までの距離が $100 \mathrm{~mm}$ となるように設置する. フォグマシーン(Porta smoke PS-2006, Dainichi Co., Ltd.)から発生した煙は $\varphi 5 \mathrm{~mm}$ の導入管を通り整流格子の上流から下流へ流れ出る. 煙を明 確に観察するために LED ライトを適宜用い，図 5 に示寸テストセクションの入口から見て右側にハイスピード カメラ(FASTCAM SA2, Photron Ltd.)を設置し煙の動きを撮影する．撮影した動画からリング状平板に垂直なネッ クレス渦の断面が明瞭に確認できる図を複数選択し，画像解析ソフト Image J (Rasband, 2020)を用いてネックレス 渦断面の内側の面積 $A_{V}\left[\mathrm{~mm}^{2}\right]$ を検出する. この検出される面積を等面積の円形に置き換え，断面の直径（等価直 径） $D_{V}\left[\mathrm{~mm}^{2}\right]$ を以下の式(8)を用いて算出する.

$$
D_{V}=2 \sqrt{\frac{A_{V}}{\pi}}
$$

\section{4. 実験結果および考察}

\section{$4 \cdot 1$ 単独円柱翼風車におけるネックレス渦の可視化}

図 8 に単独円柱翼風車において，円柱翼とリング状平板の交差部を煙により可視化した一例を示す．カメラは 流れに対して垂直でリング状平板を真横から観察する位置に設置した。煙は左から右に流れ，円柱翼は下に向か って回転している．図 8(a)は円柱翼が煙を含む流線を通過する直前の写真である．円柱の進行方向前方では渦は 確認されず，煙が円柱翼とリング状平板のすき間に向かって吸い込まれる様子が確認される. 図 8(b)の3 枚の写 真は煙を含む流線が円柱翼の後半にさしかかった状態の連続写真である. 円柱翼とリング状平板のすき間部にお いて, 図 3(b)の模式図に示したネックレス渦の断面が確認される. 1 枚目の写真では煙はリング状平板の幅の中 心近傍の流れとネックレス渦の断面を可視化している.このとき観察される輪状の領域はネックレス渦の回転軸 に対してほぼ垂直な断面を示しており，渦の回転軸方向から可視化している状態である．時間経過に伴い円柱翼 が回転し，煙のあたる位置が円柱翼の半径内側にずれてくる. 3 枚目の写真では円柱翼を斜め上から見下ろす状 態となっており，円柱翼に沿って形成されるネックレス渦をリング状平板の内側に近い位置での断面と，ネック レス渦の外周部であるチューブ状の領域の一部を斜め上から見た視野で捕らえている. 3 枚の連続写真で円柱翼 が下方に移動するにもかかわらずネックレス渦の断面の位置が動かずに直径が大きくなるように見えるのは，こ のように円柱翼の回転による視野の変化と煙のあたる位置のずれによるものである. この可視化によって，ネッ クレス渦が円柱の進行方向逆側の寸き間部に定常的に形成されることを示し，数值解析により得られた結果 (Hemsuwan et al., 2018) と一致することが確認された. 
Tip of cylinder blade

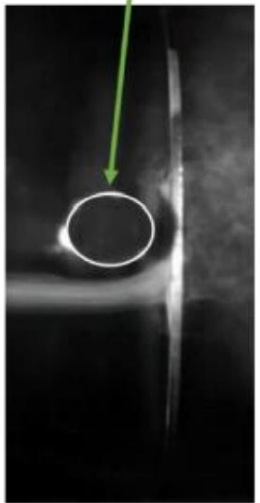

(a) Suction flow forward in the rotational direction
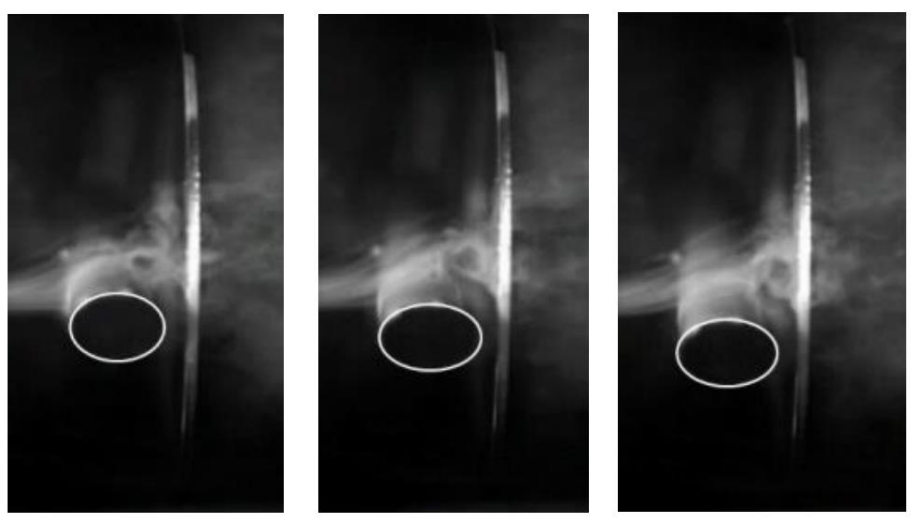

(b) Necklace vortex formed steadily behind the rotating cylinder

Fig. 8 Visualization of flow around cross-section of stepped circular cylinder blade and ring-plate. Cross-section of cylinder blade tip is marked with a white line. Cylinder blade rotates downward and necklace vortex is generated on opposite side of moving direction, i.e., upper side of stepped circular cylinder blade. Cross section of necklace vortex rotates clockwise.

\section{4-2 段付き円柱翼風車を用いたネックレス渦の可視化}

図 9 に段付き円柱翼風車の $d=20 \mathrm{~mm}$ における $N=2$ および $d=28 \mathrm{~mm}$ における $N=2 ， 4,8$ のネックレス渦の 可視化の結果の一例を示す. 図 8 の可視化結果と同様に煙は左から右に流れ, 円柱翼は下に向かって回転する. いずれの場合も時計回りに回転するネックレス渦の断面が円柱の進行方向逆側のすき間部に定常的に形成され， 円柱翼の回転に追従している様子が確認された. 各実験条件を(a) $d=20 \mathrm{~mm}, N=2$, (b) $d=28 \mathrm{~mm}, N=2$, (c) $d$ $=28 \mathrm{~mm}, N=4,(\mathrm{~d}) d=28 \mathrm{~mm}, N=8$ とし, 可視化された多数の渦の写真から断面における渦の等価直径の平均 $D_{V A v e}$ と標準偏差 SD を求め, 図 10 によとめた. 実験条件(a)と(b)の同一翼数 $N=2$ では, 実験条件(a)の $D_{V A v e}$ に対 して(b)の結果が約 1.3 倍となり，この比は円柱翼直径の比 $28 / 20=1.4$ とほぼ一致した. 従って，ネックレス渦の 断面の大きさは円柱翼直径 $d$ の増加に比例して大きくなる．また，実験条件(b)の SD は実験条件(a)と比較して大 きくなったことから, 円柱直径 $d$ が大きいほどネックレス渦が変形しやすく, ネックレス渦による揚力が変動し やすいことが示唆される．また，実験条件(b) (d)の同一の翼直径 $d=28 \mathrm{~mm}$ では， $D_{V A v e}$ はほぼ等しくなり，ネッ クレス渦の形成は翼数の影響を受けないことが示された. 図 $9(\mathrm{~d})$ に示す $N=8$ の場合, 回転方向の前方に位置す る円柱翼から発生するネックレス渦と, 後方の円柱翼に向かって発生する流れの吸い込みが隣り合わせで発生し ている様子が観察できる，本観察および条件では，実験条件(d)の SD は実験条件(b)よりも小さくなり，さらに $N$ が大きいことによるネックレス渦の形成および吸い込みの乱れは観察されなかった．また，実験条件 $(\mathrm{c})$ の $N=4$ における SD も実験条件(b)よりも小さくなった. 実験条件(c)では実験条件(d) と同様に，ネックレス渦および吸い 込みの形成の乱れは観察されなかったが，これらの形成におよぼす翼数の影響が，実験条件(c)ですでに表れてい ると考えらえる。しかし，実験条件(d)から翼同士の間隔をさらに狭くすることにより，回転に関わる後流による 干渉効果が発生しネックレス渦の形成が乱れ，揚力が低下寸ることが想定される. 


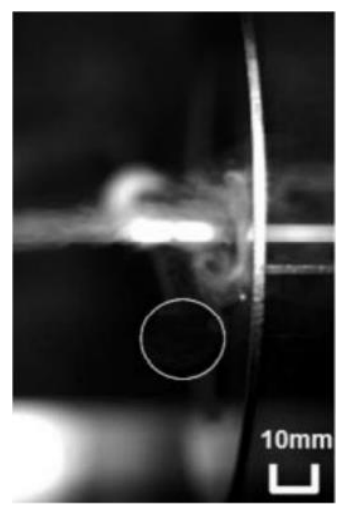

(a) $d=20 \mathrm{~mm}, N=2$

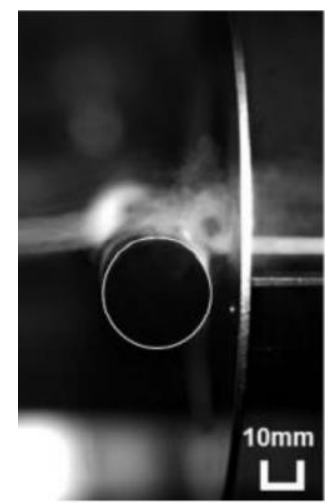

(b) $d=28 \mathrm{~mm}, N=2$

$$
\left(D_{V}=4.76 \mathrm{~mm}\right)
$$

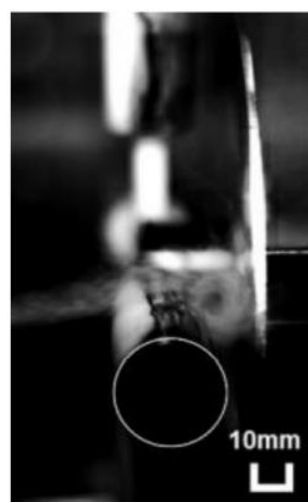

(c) $d=28 \mathrm{~mm}, N=4$

$$
\left(D_{V}=6.48 \mathrm{~mm}\right)
$$

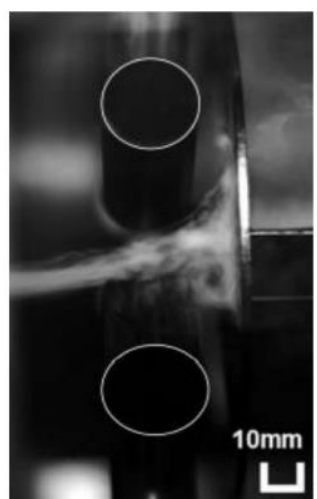

(d) $d=28 \mathrm{~mm}, N=8$

$\left(D_{V}=6.26 \mathrm{~mm}\right)$

Fig. 9 Visualization of necklace vortex forming behind stepped circular cylinder blades in each cylinder blade diameter and blade number. Cross-section of cylinder blade tip is marked with a white line. Cylinder blade rotates downward and necklace vortex is generated on upper side of stepped circular cylinder blade. Cross section of necklace vortex rotates clockwise.

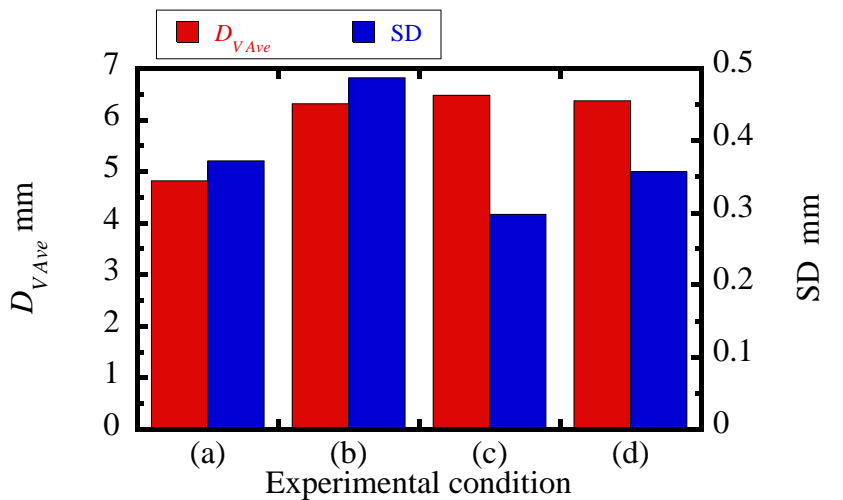

Fig. 10 Equivalent diameter of necklace vortex obtained by image analysis at each cylinder blade diameter and blade number.

\section{$4 \cdot 3$ 単独円柱翼風車の回転特性}

主流速度 $U=10 \mathrm{~m} / \mathrm{s}$ 一定下において単独円柱翼を任意の回転数で回転させることで相対迎角 $\alpha$ を変化させ，そ の時に回転軸に作用するトルク $T_{z}$ から流体力係数 $C_{z}$ を算出した. 図 11 にすき間比 $s / d=0.1$ と 0.4 における $\alpha$ と $C_{z}$ の関係を示寸. $s / d=0.1$ の場合, $C_{z}$ は $\alpha$ の増加に対して単調に増加し，いずれの $\alpha$ においても正の值を示した. これは円柱翼の回転方向に対して反対の力，すなわち回転を抑制する力が作用し，回転数が大きくなるとその力 が強くなることを意味する．この力により， $s / d=0.1$ では円柱翼に初速として回転を与えても回転が停止するこ とが示唆される. 一方,$s / d=0.4$ では $\alpha \leq 11 \mathrm{deg}$ において $C_{z}$ が負の值を示した. この領域においては，円柱翼は 回転を開始寸ると回転方向に力を受け，加速していくことを意味する．また，この $C_{z}$ の值が小さいほど，より大

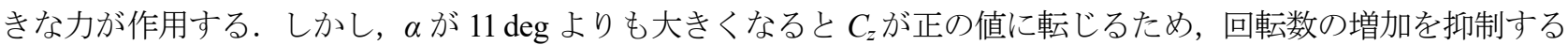
方向に力が作用する.

図 11 に示寸実験結果と円柱翼の挙動の関係を調べるために，円柱翼風車の回転軸先端に取り付けられたモー タおよびトルクメータを取り外し，主流速度 $U=10 \mathrm{~m} / \mathrm{s}$ 一定下においてすき間比を $s / d=0 \sim 0.5$ の範囲で段階的に 増加させ，円柱翼の回転が安定した際の回転数を測定した. 図 12 に各 $s / d$ において測定された円柱翼の回転数 $n$ と，Uと $n$ を式(2), (3)の代入し求めた相対迎角 $\alpha$ を示寸. 図 11 で $C_{z}$ を測定した条件のひとつである $s / d=0.1$ を 含む $0 \leq s / d<0.35$ の範囲では円柱翼に初速として回転を与えても回転が停止した. $s / d=0.4$ では回転数 $n=245$ $\mathrm{rpm}$ ，すなわち相対迎角が $\alpha=11.5 \mathrm{deg}$ 程度となるように円柱翼は定常回転した．この $\alpha$ の值は，図 11 中の寸き 間比 $s / d=0.4$ において $C_{z}$ の符号が反転する付近の $\alpha$ の值とよく一致する. すなわち，軸受けのまさつ抵抗などの 負荷が小さい状態で円柱翼が風により自由回転するとき， $C_{z}=0$ となるように回転数は決定される. また，円柱 
翼は $s / d=0.35$ で自立的に定常回転を開始し, $s / d \geq 0.35$ において回転数は $s / d$ の増加に伴い単調に減少した. この 結果から， $s / d=0.35$ が縦渦による回転方向に作用寸る力が得られる臨界条件であり， $s / d$ にって $C_{z}=0$ となる $\alpha$ の值は変化することが示された。

円柱翼風車のモータおよびトルクメータを取り外した状態で，すき間比を $s / d=0.35$ に設定し，主流速度 $U$ を 段階的に増加させ, 円柱翼の回転が安定した際の回転数 $n$ を測定した. $U$ と $n$ の関係を図 13(a)に示寸. さらに, $U$ と $n$ を式(2), (3)に代入し求めた相対迎角 $\alpha$ と $U$ の関係を図 13(b)に示寸. $U$ と $n$ の関係は図 13(a)に示すとおり 原点を通らないが，カットイン後は $U$ の増加に対して直線的に $n$ が増加した。この結果では $U=12 \mathrm{~m} / \mathrm{s}$ までの結 果を示しているが，その後の実験で計測系の限界である $U=35 \mathrm{~m} / \mathrm{s}$ までこの直線関係が継続した．この直線が原 点を通らないのは軸受けのまさつなどによる機器の初期負荷によるものと考える，そこで，軸受けまさつによる 回転開始流速の変化分 $U_{0}$ を考慮して, 式(2)中の $U$ を円柱翼風車が定常回転を開始する速度を原点とする換算流 速 $U^{\prime}\left(=U-U_{0}\right)$ に置き換え， $U^{\prime}$ と $n$ を式(2)，(3)に代入し換算相対迎角 $\alpha^{\prime}$ を算出した．図 13(b)に示すように $\alpha^{\prime} は$ U’よらず一定となり，無負荷状態であれば $C_{z}$ がゼロとなる条件を満たすように回転数が決まることが，この結 果からも示された.

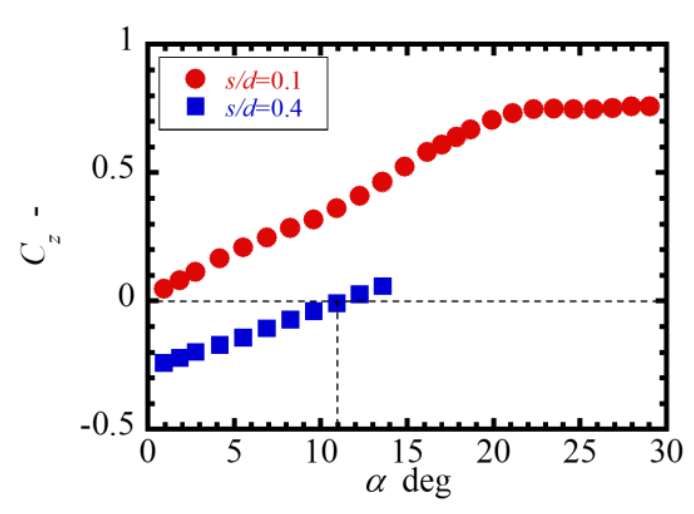

Fig. 11 Relationship between fluid force coefficient and relative attack angle in rotating circular cylinder blade at constant flow velocity. $d=20 \mathrm{~mm}, w=20 \mathrm{~mm}, L=220 \mathrm{~mm}, D=155 \mathrm{~mm}, U$ $=10 \mathrm{~m} / \mathrm{s}$.

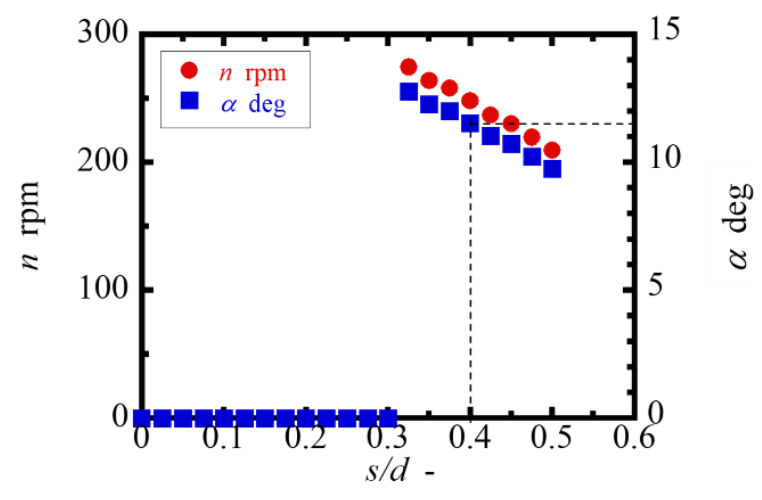

Fig. 12 Effect of gap ratio $s / d$ on rotational speed $n$ of circular cylinder blade wind turbine. $d=20 \mathrm{~mm}, w=20 \mathrm{~mm}, L=220$ $\mathrm{mm}, D=155 \mathrm{~mm}, U=10 \mathrm{~m} / \mathrm{s}$, and $s / d=0.3 \sim 0.5$.

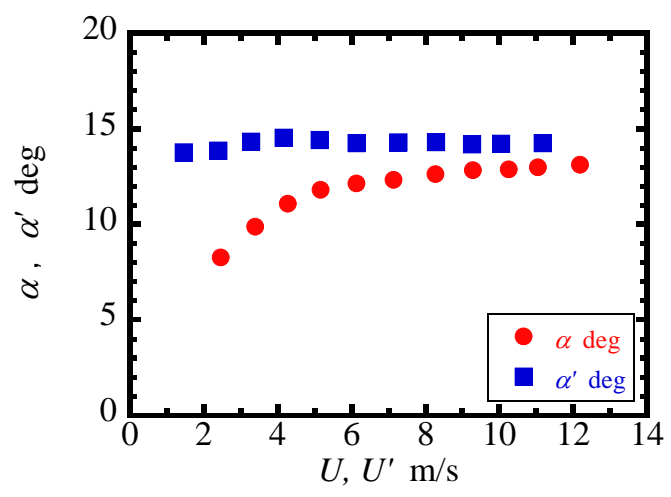

(b) Relative attack angle vs. flow velocity

(a) Rotational speed vs. flow velocity

Fig. 13 Rotational characteristics of circular cylinder blade wind turbine at increasing flow velocity. $d=20 \mathrm{~mm}, w=20 \mathrm{~mm}, L=220$ $\mathrm{mm}, D=155 \mathrm{~mm}$, and $s / d=0.35$.

\section{$4 \cdot 4$ 単独円柱翼風車の性能特性}

主流速度 $U=10 \mathrm{~m} / \mathrm{s}$ 一定下において定常回転している単独円柱翼に対して, 電磁ブレーキからの負荷を増加さ せることにより回転が停止するまで $n$ を段階的に減少させ, 円柱翼の回転が安定した際の回転数 $n$ および負荷卜 
ルク $T_{\text {brake }}$ をトルクメータにより測定した。 この $T_{\text {brake }}$ と $n$ の関係を用いて, 周速比 $\lambda$ に対するトルク係数 $C_{q}$ とパ ワー倸数 $C_{p}$ の関係を式(5) (7)により算出した. 図 14 に結果を示寸. トルク係数 $C_{q}$ は $\lambda$ の減少に伴い単調に増加 した. 図 11 に示した $C_{z}$ と $\alpha$ の関係より, $C_{z}<0$ の領域で $C_{z}$ が小さいほど縦渦の流体力が大きくなり, 円柱翼に はより大きな回転方向への力が作用する. この現象が $C_{q}$ の変化に反映されており, 電磁ブレ一キによる負荷がゼ 口に近く $\lambda$ が最大となる自由回転状態では $C_{z}$ はゼ口，すなわち回転方向への力は発生せず，負荷が増加し $\lambda$ がゼ ロに近づくほど $C_{z}$ がゼロからさらに小さくなり回転方向への力が増加した． $C_{p}$ の最大は約 0.0038 , 最大 $C_{p}$ が得 られる $\lambda$ は約 0.2 であり, 従来のプロペラ形風車と比較すると突出して低くなった. また, 上述のように $C_{q}$ は $\lambda$ の減少に伴い全領域にわたって直線的に増加するため, これらの特徵は抗力型であるサボニウス形風車に類似し ており，揚力で回転する風車でありながら抗力型と同等の性能特性を持つ.しかし，稼働周速比範囲はサボニウ ス形風車よりもさらに低周速比に位置した(山本他, 2018).

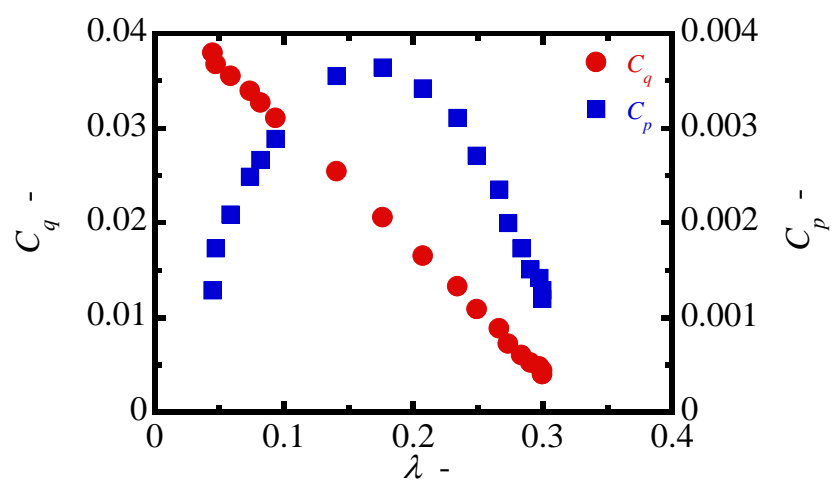

Fig. 14 Performance characteristics of circular cylinder blade wind turbine. $d=20 \mathrm{~mm}, w=20 \mathrm{~mm}, L=220 \mathrm{~mm}, D=155 \mathrm{~mm}$, and $s / d=0.35$.

\section{5. 結 言}

本論文では，流れの上流に円柱とその下流に平板が配置された十字交差系において，円柱が平板に沿って平行 移動することで縦渦が定在的に発生し定常揚力が得られる現象に基づいて, 円柱を動翼とする風車を作成し回転 特性や風車性能特性を解明した。結論を以下に示寸.

(1) 可視化によりネックレス渦が円柱翼の進行方向逆側の寸き間部に定常的に形成され, 数值解析により得ら れた結果と一致することを確認した。

(2) 円柱翼とリング状平板の交差部に形成されるネックレス渦の断面直径は円柱翼の直径に大きく依存し, 翼 数の増加の影響は小さいが翼数の増加は渦の大きさの不均一性を誘起した.

(3) 円柱翼に作用する流体力係数 $C_{z}$ は円柱翼の回転数と主流速度より幾何学的に決まる相対迎角の増加の伴 い単調増加した. 円柱翼とリング状平板の寸き間比が 0.35 未満の場合, $C_{z}$ は相対迎角によらず正の值を示 し, 初動を与えても回転を抑制する方向の力が作用して回転が停止した. 寸き間比が 0.35 以上では相対迎 角が所定の範囲で $C_{z}$ が負の值を示し, 初動を与えるとその方向に向けて加速した. 回転数が増加して相対 迎角が増加し $C_{z}=0$ となる流速に達すると加速度がゼロとなり定常回転状態となった.

(4) 流速増加に対する自由回転状態の円柱翼の回転数 $n$ は, $U$ によらず $C_{z}=0$ となる $\alpha$ 一定となるように決定 された.

（5） 円柱翼風車のトルク特性は相対迎角 $\alpha$ と $C_{z}$ の関係から得られたとおり回転負荷の増加に伴い直線的にト ルクが増加した。この出力特性は抗力型であるサボニウス形風車に類似している.

\section{文献}

裴憲民, 高橋勉, 白樫正高, 十字交差 2 円柱から流出する縦渦の特性, 日本機械学会論文集 B 編, Vol. 58, No. 
549(1992), pp.1572-1579.

裴憲民，高橋勉，白樫正高，下流に設置された円柱によるカルマン渦励振抑制効果，日本機械学会論文集 B 編, Vol. 59, No. 557(1993), pp.1-7.

Bernitsas, M. M., Raghavan, K., Ben-Simon, Y. and Garcia, E. M. H., VIVACE (Vortex Induced Vibration Aquatic Clean Energy): a new concept in generation of clean and renewable energy from fluid flow, Journal of Offshore Mechanics and Arctic Engineering, Vol. 130, Issue 4 (2008), 041101.

Blevins, R. D., Flow-induced vibration 2nd edition (2001), pp.43-60, 82-84, Van Nostrand Reinhold.

Fox, T. A., Flow visualization at the center of a cross composed of tubes, International Journal of Heat and Flow, Vol. 11, Issue 2 (1990), pp.160-162.

Fox, T. A., Wake characteristics of two circular cylinders arranged perpendicularly to each other, ASME Journal of Fluids Engineering, Vol. 113, Issue 1 (1991), pp.45-50.

Hemsuwan, W., Sakamoto, K. and Takahashi, T., Numerical investigation of lift-force generation on a moving circular cylinder in a uniform flow driven by longitudinal vortex, Journal of Fluids and Structures, Vol. 83, Issue 20 (2018), pp.448-470.

加藤直人, 小出瑞康, 高橋勉, 白樫正高, 円柱の下流に十字交差配置された帯状の平板による振動制御 (第 1 報, 固定系からの縦渦流出), 日本機械学会論文集 B 編, Vol. 73, No. 728 (2007), pp.957-964.

Kato, N., Koide, M., Takahashi, T. and Shirakashi, M., VIVs of a circular cylinder with a downstream strip-plate in cruciform arrangement, Journal of Fluids and Structures, Vol. 30 (2012), pp.97-114.

川畑佑介, 高橋勉, 萩野谷剛, 白樫正高, 角柱のクロスフロー振動に対する後流平板の干渉効果, 日本機械学会論 文集 B 編, Vol.77, No.775 (2011),pp.647-658.

小出瑞康，高橋勉，白樫正高，風洞実験における低流速測定を目的としたリング流速計の試作，日本機械学会論文 集 B 編, Vol. 67, No. 657 (2001), pp.1105-1111.

Koide, M., Ootani, K., Yamada, S., Takahashi, T. and Shirakashi, M., Vortex excitation caused by longitudinal vortices shedding from cruciform cylinder system in water flow, JSME International Journal, Series B, Fluids and Thermal Engineering, Vol. 49, No. 4 (2006), pp.1043-1048.

小出瑞康, 関崎敬広, 山田修一, 高橋勉, 白樫正高, 水流による渦励振を利用したマイクロ発電の将来性と実証試 験，日本機械学会論文集 B 編, Vol. 77, No. 775 (2011), pp.702-714.

Koide, M., Takahashi, T., Shirakashi, M. and Salim, S. A. Z. B. S., Three-dimensional structure of longitudinal vortices shedding from cruciform two-cylinder systems with different geometries, Journal of Visualization, Vol. 20, Issue 4 (2017), pp.753-763.

Rasband, W. S., ImageJ, available from <http://rsb.info.nih.gov/ij/>, (参照日 2020 年 12 月 8 日).

Shirakashi, M., Bae, H. M., Sano, M. and Takahashi, T., Characteristics of periodic vortex shedding from two cylinders in cruciform arrangement, Journal of Fluids and Structures, Vol. 8, Issue 3 (1994), pp.239-256.

Takahashi, T., Baranyi, L. and Shirakashi, M., Configuration and frequency of longitudinal vortices shedding from two circular cylinders in cruciform arrangement, 可視化情報学会学会誌, Vol. 19, No. 75 (1999), pp.328-336.

高橋勉, 吉武裕美子, 小又直, 植木由記子, 流体発電用回転装置および流体発電装置, 特願 2016-568339 (2016).

Takahashi, T., Yoshitake, Y., Sakamoto, K. and Hemsuwan, W., An innovative wind/water turbine with circular propeller driven by longitudinal vortex, Proceedings of the 15th WWEC2016 TOKYO conference (2016), PS-A-5.

山本誠, 太田有, 新関良樹, 宮川和芳, 流体機械 - 基礎理論から応用まで - (2018), pp.197-205, 共立出版株式会社.

\section{References}

Bae, H. M., Takahashi, T. and Shirakashi, M., Characteristics of longitudinal vortices shedding from two circular cylinders in cruciform arrangement, Transactions of the Japan Society of Mechanical Engineers, Series B, Vol. 58, No. 549 (1992), pp.1572-1579 (in Japanese).

Bae, H. M., Takahashi, T. and Shirakashi, M., Suppression of Karman vortex excitation of a circular cylinder by another cylinder located downstream in cruciform arrangement, Transactions of the Japan Society of Mechanical Engineers, Series B, Vol. 59, No. 557 (1993), pp.1-7 (in Japanese).

Bernitsas, M. M., Raghavan, K., Ben-Simon, Y. and Garcia, E. M. H., VIVACE (Vortex Induced Vibration Aquatic Clean Energy): a new concept in generation of clean and renewable energy from fluid flow, Journal of Offshore Mechanics and Arctic Engineering, Vol. 130, Issue 4 (2008), 041101.

Blevins, R. D., Flow-induced vibration 2nd edition (2001), pp.43-60, 82-84, Van Nostrand Reinhold. 
Fox, T. A., Flow visualization at the center of a cross composed of tubes, International Journal of Heat and Flow, Vol. 11, Issue 2 (1990), pp.160-162.

Fox, T. A., Wake characteristics of two circular cylinders arranged perpendicularly to each other, ASME Journal of Fluids Engineering, Vol. 113, Issue 1 (1991), pp.45-50.

Hemsuwan, W., Sakamoto, K. and Takahashi, T., Numerical investigation of lift-force generation on a moving circular cylinder in a uniform flow driven by longitudinal vortex, Journal of Fluids and Structures, Vol. 83, Issue 20 (2018), pp.448-470.

Kato, N., Koide, M., Takahashi, T. and Shirakashi, M., Vibration control for a circular cylinder by a strip-plate set downstream in cruciform arrangement : 1st report, Influence of a downstream strip-plate on the shedding of longitudinal vortices from fixed system, Transactions of the Japan Society of Mechanical Engineers, Series B, Vol. 73, No. 728 (2007), pp.957-964 (in Japanese).

Kato, N., Koide, M., Takahashi, T. and Shirakashi, M., VIVs of a circular cylinder with a downstream strip-plate in cruciform arrangement, Journal of Fluids and Structures, Vol. 30 (2012), pp.97-114.

Kawabata, Y., Takahashi, T., Haginoya, T. and Shirakashi, T., Interference effect of downstream strip plate on the crossflow vibration of a square cylinder, Transactions of the Japan Society of Mechanical Engineers, Series B, Vol. 77, No. 775 (2011), pp.647-658 (in Japanese).

Koide, M., Takahashi, T. and Shirakashi, M., Development of a ring-type vortex anemometer for low-velocity wind tunnel experiment, Transactions of the Japan Society of Mechanical Engineers, Series B, Vol. 67, No. 657 (2001), pp.1105-1111 (in Japanese).

Koide, M., Ootani, K., Yamada, S., Takahashi, T. and Shirakashi, M., Vortex excitation caused by longitudinal vortices shedding from cruciform cylinder system in water flow, JSME International Journal, Series B, Fluids and Thermal Engineering, Vol. 49, No. 4 (2006), pp.1043-1048.

Koide, M., Sekizaki, T., Yamada, S., Takahashi, T. and Shirakashi, M., Prospect of micro power generation utilizing VIV in small stream based on verification experiments of power generation in water tunnel, Transactions of the Japan Society of Mechanical Engineers, Series B, Vol. 77, No. 775 (2011), pp.702-714 (in Japanese).

Koide, M., Takahashi, T., Shirakashi, M. and Salim, S. A. Z. B. S., Three-dimensional structure of longitudinal vortices shedding from cruciform two-cylinder systems with different geometries, Journal of Visualization, Vol. 20, Issue 4 (2017), pp.753-763.

Rasband, W. S., ImageJ, available from <http://rsb.info.nih.gov/ij/>, (accessed on 8 December, 2020).

Shirakashi, M., Bae, H. M., Sano, M. and Takahashi, T., Characteristics of periodic vortex shedding from two cylinders in cruciform arrangement, Journal of Fluids and Structures, Vol. 8, Issue 3 (1994), pp.239-256.

Takahashi, T., Baranyi, L. and Shirakashi, M., Configuration and frequency of longitudinal vortices shedding from two circular cylinders in cruciform arrangement, Journal of the Visualization Society of Japan, Vol. 19, No. 75 (1999), pp.328-336.

Takahashi, T., Yoshitake, Y., Komata, N. and Ueki, Y., Rotary device for fluid power generation and fluid power generation Device, Japanese Patent Application No. 2016-568339 (2016).

Takahashi, T., Yoshitake, Y., Sakamoto, K. and Hemsuwan, W., An innovative wind/water turbine with circular propeller driven by longitudinal vortex, Proceedings of the 15th WWEC2016 TOKYO conference (2016), PS-A-5.

Yamamoto, M., Oota, Y., Niizeki, Y. and Miyagawa, K., Fluid machinery -From fundamental theory and applications- (2018), pp.197-205, Kyoritsu Shuppan Co., Ltd (in Japanese). 